OPEN ACCESS

Edited by:

Akio Kanai,

Keio University, Japan

Reviewed by:

Gota Kawai,

Chiba Institute of Technology, Japan

Kiong $\mathrm{Ho}$,

University of Tsukuba, Japan

Stefan Weitzer,

Medizinische Universität Wien, Austria

${ }^{*}$ Correspondence:

Yohei Kirino

yohei.kirino@jefferson.edu

Specialty section:

This article was submitted to

RNA

a section of the journal

Frontiers in Genetics

Received: 28 September 2018 Accepted: 06 November 2018

Published: 27 November 2018

Citation:

Shigematsu M, Kawamura T and Kirino Y (2018) Generation

of 2', 3'-Cyclic Phosphate-Containing

RNAs as a Hidden Layer of the

Transcriptome. Front. Genet. 9:562.

doi: 10.3389/fgene.2018.00562

\section{Generation of $2^{\prime}, 3^{\prime}$-Cyclic Phosphate-Containing RNAs as a Hidden Layer of the Transcriptome}

\author{
Megumi Shigematsu, Takuya Kawamura and Yohei Kirino* \\ Computational Medicine Center, Sidney Kimmel Medical College, Thomas Jefferson University, Philadelphia, PA, \\ United States
}

Cellular RNA molecules contain phosphate or hydroxyl ends. A $2^{\prime}, 3^{\prime}$-cyclic phosphate (cP) is one of the $3^{\prime}$-terminal forms of RNAs mainly generated from RNA cleavage by ribonucleases. Although transcriptome profiling using RNA-seq has become a ubiquitous tool in biological and medical research, cP-containing RNAs (cP-RNAs) form a hidden transcriptome layer, which is infrequently recognized and characterized, because standard RNA-seq is unable to capture them. Despite cP-RNAs' invisibility in RNA-seq data, increasing evidence indicates that they are not accumulated simply as non-functional degradation products; rather, they have physiological roles in various biological processes, designating them as noteworthy functional molecules. This review summarizes our current knowledge of cP-RNA biogenesis pathways and their catalytic enzymatic activities, discusses how the CP-RNA generation affects biological processes, and explores future directions to further investigate cP-RNA biology.

Keywords: $2^{\prime}, 3^{\prime}$-cyclic phosphate (cP), cP-containing RNA (cP-RNA), cP-RNA-seq, ribonuclease, tRNA half, noncoding RNA (ncRNA), angiogenin (ANG)

\section{INTRODUCTION}

After transcription, newly synthesized RNA molecules must undergo maturation steps to become functional molecules, and unnecessary RNAs are subjected to turnover. In both the RNA maturation and turnover mechanisms, enzymatic cleavage of RNA molecules plays a crucial role. When cleaved, RNAs can generally possess a hydroxyl group $(\mathrm{OH})$, a phosphate $(\mathrm{P})$, or a $2^{\prime}, 3^{\prime}-$ cyclic phosphate $(\mathrm{cP})$ at their termini. While $\mathrm{OH}$ and $\mathrm{P}$ can be found at both the $5^{\prime}$ - and $3^{\prime}$-ends of RNAs, a cP presents only at the $3^{\prime}$-end of RNAs in which the $2^{\prime}$ - and $3^{\prime}$-positions of ribose is bridged by the phosphate (Figure 1). Catalytic machineries of RNA cleavage determine the terminal phosphate states of the generated RNA molecules, which is not just a consequence of the cleavage, but, in many cases, is critical for further RNA maturations and functions. The current, standard RNA-sequencing (RNA-seq) methods rely on $5^{\prime}-\mathrm{P} / 3^{\prime}-\mathrm{OH}$ ends of RNAs, and thus, RNAs with a cP (cP-containing RNAs: $\mathrm{cP}-\mathrm{RNAs}$ ) cannot be captured because $\mathrm{cP}$ end cannot be ligated to the $3^{\prime}$-adapter by ATP-dependent ligase. Consequently, cP-RNAs are "invisible" in RNA-seq data and therefore form a hidden component of transcriptome. However, accumulating evidence indicates that the cP-RNA generation is significant in various biological processes. Here, we summarize our 


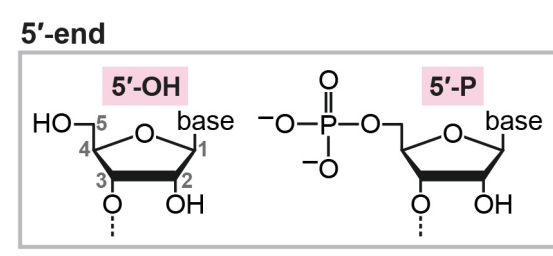

3'-end

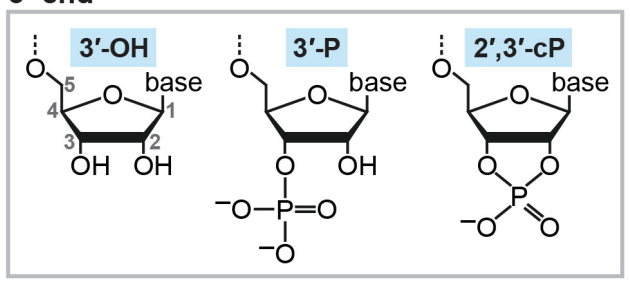

FIGURE 1 | Chemical structures of RNA termini.

knowledge of cP-RNAs' biogenesis mechanisms, expression, and molecular functions and discuss how to further interrogate $\mathrm{cP}$ RNA biology.

\section{POSSIBLE CATALYTIC MECHANISMS OF CP FORMATION}

There are multiple situations in which a $\mathrm{cP}$ is formed at the $3^{\prime}$ end of RNA molecules. cP frequently appears as an intermediate form during RNA cleavage by many endoribonucleases [e.g., pancreatic ribonuclease (RNase $A$ ), RNase $T_{1}$, and RNase $T_{2}$ ], which eventually generate RNAs with $3^{\prime}-\mathrm{P} / 5^{\prime}-\mathrm{OH}$ ends (Cuchillo et al., 1997; Irie, 1997; Nichols and Yue, 2008). RNA cleavage by these enzymes is composed of two steps: (i) transesterification (transphosphorylation), forming an intermediate $\mathrm{cP}$, and (ii) $\mathrm{cP}$ hydrolysis to generate a 3'-P (Fabian and Mantsch, 1995; Lilley, 2011) (Figure 2A). RNase A, the best studied enzyme among such endoribonucleases, contains a catalytic triad, His12, Lys41, and His119, which, especially the two histidines, serve as general acidbase catalysts during both steps (Roberts et al., 1969; Thompson and Raines, 1994; Cuchillo et al., 2011). Step (i) is initiated with 2 '-OH deprotonation by a base catalyst, His 12 , followed by nucleophilic attack of the phosphorus by the generated $2^{\prime}$-oxygen (O), which causes transesterification to form a $2^{\prime}, 3^{\prime}$-cP. His119 assists the reaction as an acid catalyst by donating a proton to the leaving group, forming a $5^{\prime}-\mathrm{OH}$ end. Lys41 forms a hydrogen bond with $2^{\prime}-\mathrm{O}$ to transiently stabilize the $\mathrm{cP}$. In step (ii), to hydrolyze the $\mathrm{cP}$, His119 serves as a base catalyst to remove a proton from the vicinal water molecule, while His 12 serves as an acid catalyst by donating a proton to form $2^{\prime}-\mathrm{OH}$, generating a $3^{\prime}$-P as a final form.

Although the above case produces a $\mathrm{cP}$ just as an intermediate form, many ribonucleases, as summarized in Table 1, generate a $\mathrm{cP}$ as a final form via their RNA cleavage that only conducts step (i) without proceeding to step (ii) (Figure 2B). As a well-studied example, RNA cleavage by angiogenin (ANG), an endoribonuclease belonging to the RNase A superfamily
(Dyer and Rosenberg, 2006; Sheng and $\mathrm{Xu}, 2016$ ), yields a cP end (Shapiro et al., 1986). ANG contains the catalytic triad, His13, Lys40, and His114, which are well-conserved among RNase A superfamily members, but shows $10^{5}-10^{6}$-fold lower ribonucleolytic activity compared to RNase A (Shapiro et al., 1986; Harper and Vallee, 1989). Certain unique structural features of ANG can explain this low catalytic activity. ANG's substrate binding pocket is obstructed by Gln117 (Acharya et al., 1994; Russo et al., 1994) (Figure 2C), which is stabilized by a hydrogen bond with Thr44 (Leonidas et al., 1999, 2002; Holloway et al., 2004). Two hydrogen bonds from Asp116 and Ser118 further stabilize Gln117's obstructive position (Russo et al., 1994). These steric hindrances would cause decreased substrate accessibility, possibly leading to low cleavage and $\mathrm{cP}$ hydrolysis activities. Indeed, a single mutation of Gln117 to Gly showed at least a $\sim 20$-fold increase in ribonuclease activity, as well as a $\sim 28$-fold increase in cP hydrolysis activity (Russo et al., 1994; Leonidas et al., 2002). In addition, Asp116 could contribute to low cP hydrolysis activity as well as low cleavage activity. While the corresponding Asp121 of RNase A forms a hydrogen bond with catalytic His119, presumably to support its imidazole ring orientation, Asp116 of ANG does not support catalytic His114 but forms two hydrogen bonds with Ser118 (Leonidas et al., 2002). The lack of support for His 114 should have an adverse effect on the $\mathrm{CP}$ hydrolysis reaction because His114 would have initiated the reaction as a base catalyst, possibly leaving a $\mathrm{cP}$ as a final form.

RNA cleavage by colicin E5, a cytotoxic endoribonuclease found in Escherichia coli, also yields a cP as a final form (Ogawa et al., 1999; Ogawa et al., 2006), presumably due to cP structure stabilization. The ribonuclease domain of colicin E5 does not contain histidines, the most frequently utilized catalytic residues (Bartlett et al., 2002), but possesses Arg33 and Lys25 (numbering from C-terminal domain) as catalytic residues (Yajima et al., 2006; Inoue-Ito et al., 2012). Although the catalytic mechanism remains to be further examined, these residues, along with Ile94 that supports the orientation of Arg33, might stabilize a cP structure (Inoue-Ito et al., 2012), which would contribute to generating a $\mathrm{cP}$ as a final form. A $\mathrm{cP}$ structure may also be stabilized through interaction with a protein during RNA cleavage of a eukaryotic cP-forming exoribonuclease, $\mathrm{U}$ six biogenesis protein 1 (USB1), also known as mutated in poikiloderma with neutropenia protein 1 (MPN1). USB1 contains two well-conserved His-x-Ser (HxS) catalytic motifs in the active site cleft (Mroczek et al., 2012; Hilcenko et al., 2013). It is speculated that, while His 120 and His208 in these motifs serve as general acid-base catalysts, Ser122 and Ser210 in these motifs coordinate the oxygens in a cP after transesterification, potentially stabilizing a $\mathrm{cP}$ structure as a final form by preventing further hydrolysis.

While $\mathrm{cP}$ end is predominantly formed by ribonucleasecatalyzed transesterification, RNA $3^{\prime}$-terminal phosphate cyclase (RtcA) can catalyze de novo $\mathrm{cP}$ formation by a distinct molecular mechanism involving the following three steps (Genschik et al., 1997, 1998; Billy et al., 2000; Filipowicz, 2016). First, RtcA is autoadenylylated with ATP to form a covalent RtcAAMP intermediate. The autoadenylylation is initiated by a His309 (in E. coli RtcA; His320 in human RtcA)-mediated 


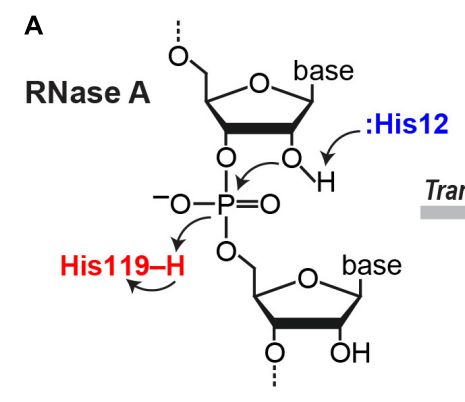

B

B

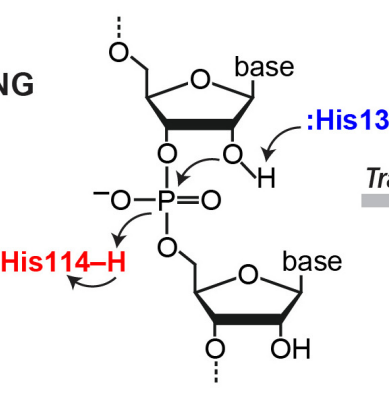

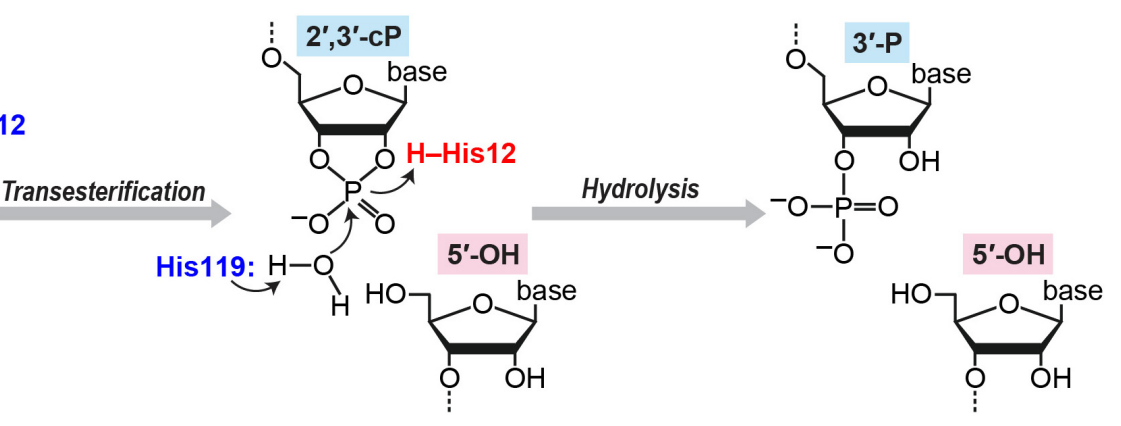

C

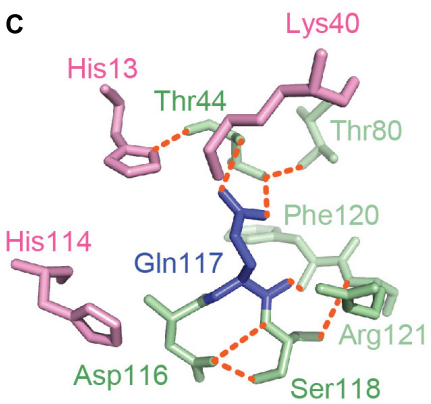

FIGURE 2 | CP formation via RNA cleavage by ribonucleases. (A,B) Cleavage reactions catalyzed by RNase A (A) and ANG (B). (C) Structure of ANG catalytic site (human wild type, PDB ID: 1B11). Three catalytic residues are shown in pink, and the residues forming a substrate binding pocket and/or associating with Gln117 are shown in green. Orange dotted lines indicate the hydrogen bonds that particularly support Gln117's obstructive position (Leonidas et al., 1999, 2002; Holloway et al., 2004).

nucleophilic attack of ATP $\alpha$-phosphorus, followed by covalent bond formation and pyrophosphate $(\mathrm{PPi})$ release. Second, the holoenzyme then transfers the AMP to $3^{\prime}-\mathrm{P}$ of the substrate RNA to form an RNA with $3^{\prime}-\mathrm{PP}-5^{\prime} \mathrm{A}$. Third, the energetically unstable phosphoanhydride bond between the two phosphates is cleaved by $2^{\prime}-\mathrm{OH}$-mediated attack, resulting in $\mathrm{cP}$ formation and releasing AMP.

\section{cP-FORMING ENZYMES}

\section{Ribonucleases}

Although the detailed molecular basis of $\mathrm{cP}$ formation remains to be determined, RNA cleavage by many ribonucleases produces a $\mathrm{cP}$ as a final, predominant form, generating $\mathrm{cP}-\mathrm{RNAs}$ (Table 1). A tRNA splicing endonuclease is one of the oldest ribonucleases known to generate cP-RNAs (Abelson et al., 1998; Hopper and Phizicky, 2003; Yoshihisa, 2014). In eukaryotes, precursors of some tRNAs, such as tRNA ${ }^{\text {LeuCAA }}$, tRNA ${ }^{\text {IleUAU }}$, and tRNA ${ }^{\text {TyrGUA }}$, contain an intronic region within their anticodon-loop (Chan and Lowe, 2016). Although the splicing activity to remove tRNA introns and $\mathrm{cP}$ formations during the splicing were discovered in the early 1980s (Peebles et al., 1983), many years and much effort were required to identify tRNA-splicing endonuclease subunit 2 (Sen2) as the endoribonuclease directly responsible for tRNA splicing (Trotta et al., 1997; Paushkin et al., 2004; Phizicky and Hopper, 2010), partly due to its membrane association property and low cellular expression level. Sen2 is a subunit of the heterotetrameric SEN complex and cleaves the $5^{\prime}$-splice site of
tRNAs to leave a cP at the $3^{\prime}$-end of $5^{\prime}$-exons (Figure 3A), whereas the $3^{\prime}$-splice site is cleaved by Sen34. As expected from its crucial role in tRNA splicing, SEN2 is an essential gene in yeast (Trotta et al., 1997). In humans, SEN2 gene mutations are associated with pontocerebellar hypoplasia (Budde et al., 2008; Namavar et al., 2011; Bierhals et al., 2013).

Angiogenin, originally identified as a protein factor promoting angiogenesis (Fett et al., 1985; Kurachi et al., 1985; Strydom et al., 1985), is another ancient enzyme that produces cPRNAs (Shapiro et al., 1986). ANG has diverse physiological roles and is associated with various pathological conditions such as cancers and neurodegenerative diseases (Tello-Montoliu et al., 2006; Gao and Xu, 2008; Sheng and Xu, 2016). tRNAs were identified as major endogenous RNA targets of ANG in Xenopus oocytes (Saxena et al., 1992), and, subsequently, ANGmediated cleavages of tRNA anticodon-loops were reported to generate functional tRNA half molecules in human cell lines (Fu et al., 2009; Yamasaki et al., 2009; Honda et al., 2015) (Figure 3B). In hormone-dependent cancer cells, ANG cleavage has been shown to occur for mature aminoacylated tRNAs, generating $5^{\prime}$-tRNA halves with a $5^{\prime}$-P and a $3^{\prime}$-terminal $\mathrm{cP}$, and $3^{\prime}$-tRNA halves with a $5^{\prime}-\mathrm{OH}$ and a $3^{\prime}$-terminal amino acid (Honda et al., 2015). Although $A N G$ homologs are only found in vertebrates (Cho and Zhang, 2006; Sheng and Xu, 2016), 5' tRNA halves expressed in Bombyx mori cells still contain a cP (Honda et al., 2017), suggesting that, even in the absence of ANG homologs, those organisms express an unidentified cP-forming endoribonuclease to cleave tRNAs and generate tRNA halves as cP-RNAs. 
TABLE 1 | Ribonucleases reported to generate a cP as a final form.

\begin{tabular}{|c|c|c|c|c|c|}
\hline Ribonuclease & Type & cP-examined organism & Target RNA & Physiological role & $\begin{array}{l}\text { Reference validating } \\
\text { the cP formation }\end{array}$ \\
\hline ANG & Endo & Human & Mature tRNAs & $\begin{array}{l}\text { Production of tRNA } \\
\text { halves (tiRNAs, } \\
\text { SHOT-RNAs) }\end{array}$ & $\begin{array}{l}\text { Shapiro et al., 1986; } \\
\text { Honda et al., } 2015\end{array}$ \\
\hline Irel & Endo & Human, S. cerevisiae & XBP1 (HAC1) mRNA & $\begin{array}{l}\text { Xbp1 mRNA splicing in } \\
\text { the UPR pathway }\end{array}$ & $\begin{array}{l}\text { Gonzalez et al., 1999; } \\
\text { Shinya et al., } 2011\end{array}$ \\
\hline PP11 & Endo & Human & (not identified) & & Laneve et al., 2008 \\
\hline Sen2 & Endo & S. cerevisiae & $\begin{array}{l}\text { Precursor tRNAs } \\
\text { containing an intron }\end{array}$ & tRNA splicing & $\begin{array}{l}\text { Peebles et al., 1983; } \\
\text { Trotta et al., } 1997\end{array}$ \\
\hline Las1 & Endo & S. cerevisiae & 37S precursor rRNA & rRNA maturation & Gasse et al., 2015 \\
\hline GCN4 & Endo & S. cerevisiae & (not identified) & & Nikolaev et al., 2010 \\
\hline zymocin ( $\gamma$-subunit) & Endo & K. lactis & $\begin{array}{l}\text { tRNAs-GluUUC, } \\
\text { LysUUU, GInUUG }\end{array}$ & $\begin{array}{l}\text { Toxin to inhibit other } \\
\text { yeasts' growth }\end{array}$ & Lu et al., 2005 \\
\hline РaT (PaOrf2) & Endo & P. acaciae & $\begin{array}{l}\text { tRNA-GInUUG, } \\
\text { GlnCUG }\end{array}$ & $\begin{array}{l}\text { Toxin to inhibit other } \\
\text { yeasts' growth }\end{array}$ & Klassen et al., 2008 \\
\hline MazF & Endo & E. coli & mRNAs, tRNAs, rRNAs & TA system & Zhang et al., 2005a \\
\hline ChpBK & Endo & E. coli & mRNA & TA system & Zhang et al., 2005b \\
\hline Colicin E5 & Endo & E. coli & $\begin{array}{l}\text { tRNAs-TyrGUA, } \\
\text { HisGUG, AsnGUU, } \\
\text { AspGUC }\end{array}$ & $\begin{array}{l}\text { Toxin to kill other } \\
\text { bacteria }\end{array}$ & $\begin{array}{l}\text { Ogawa et al., 1999, } \\
2006\end{array}$ \\
\hline Colicin D & Endo & E. coli & $\begin{array}{l}\text { tRNAs- } \\
\text { ArgACG,ArgCCG, } \\
\text { ArguCU, ArgCCU }\end{array}$ & $\begin{array}{l}\text { Toxin to kill other } \\
\text { bacteria }\end{array}$ & Tomita et al., 2000 \\
\hline prrC & Endo & E. coli & tRNA-LysUUU & $\begin{array}{l}\text { Host defense upon } \\
\text { phase infection }\end{array}$ & Amitsur et al., 1987 \\
\hline NendoU & Endo & Nidovirus & (not identified) & & Ivanov et al., 2004 \\
\hline Type IB topoisomerase & Endo & Vaccinia virus & (not identified) & & $\begin{array}{l}\text { Sekiguchi and Shuman, } \\
\text { 1997; Shuman, } 1998\end{array}$ \\
\hline USB1 (MPN1) & Exo & Human & U6 snRNA & U6 snRNA maturation & Mroczek et al., 2012 \\
\hline
\end{tabular}

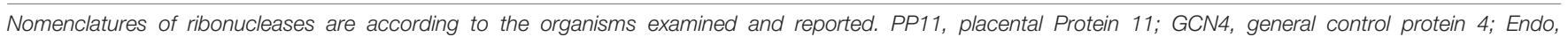
endoribonuclease; and Exo, exoribonuclease.

In vertebrates, U6 snRNA mostly contains a $\mathrm{cP}$ (Lund and Dahlberg, 1992), whereas all other snRNAs do not (Maraia and Intine, 2002). During maturation of U6 snRNA, several uridines are added to the $3^{\prime}$-end of a precursor RNA by terminal uridylyl transferase 1 (TUT1). Subsequently, USB1 (also known as MPN1), a cP-forming $3^{\prime}$ to $5^{\prime}$ exoribonuclease, excises a $3^{\prime}$ terminal uridine stretch to generate a mature $3^{\prime}$-end with four or five uridines containing a cP (Shchepachev et al., 2012; Mroczek and Dziembowski, 2013; Didychuk et al., 2018) (Figure 3C). Although USB1 belongs to the $2 \mathrm{H}$ phosphoesterase superfamily and contains a cyclic phosphodiesterase (CPDase) motif (Nasr and Filipowicz, 2000; Mazumder et al., 2002; Myllykoski et al., 2013), human USB1 lacks the CPDase activity and thus generates a $\mathrm{cP}$ as a final form. In contrast, yeast Usb1 retains the CPDase activity (Didychuk et al., 2017), generating 3'-P end of U6 snRNA (Lund and Dahlberg, 1992). It will be intriguing to address how and why the difference arose.

rRNA maturation requires a cP-forming endoribonuclease, Lethal in the absence of Ssd1 (Las1 in yeast; Las1L in human) (Castle et al., 2010; Schillewaert et al., 2012). In yeast, rRNA maturation starts from processing of a nascent 37S rRNA precursor into shorter precursors, including 27S rRNA (Henras et al., 2015; Gerstberger et al., 2017). The 27S rRNA is further cleaved by Las1 between $5.8 \mathrm{~S}$ and $25 \mathrm{~S}$ rRNA sequences, generating $7 \mathrm{~S}$ rRNA as a $5^{\prime}$-cleavage product with a $\mathrm{cP}$ (Gasse et al., 2015; Pillon et al., 2017). The cleavage is catalyzed by an N-terminal $\alpha$-helical 'higher eukaryotes and prokaryotes nucleotide-binding' (HEPN) domain of Las1, which has been defined as a conserved $\mathrm{R} \Phi \mathrm{xxxH}$ catalytic motif $(\Phi: \mathrm{N}, \mathrm{D}$, or $\mathrm{H})$ (Anantharaman et al., 2013; Pillon et al., 2017). During further processing of $7 \mathrm{~S}$ rRNA into mature 5.8S rRNA, a $\mathrm{cP}$ end of $7 \mathrm{~S}$ rRNA is removed and processed by unknown mechanisms; therefore, $\mathrm{cP}$ is absent in mature rRNAs.

$\mathrm{cP}$ is also formed in a mRNA splicing event that plays a crucial role in activating the unfolded protein response (UPR) pathway upon endoplasmic reticulum (ER) stress. Inositol-requiring enzyme 1 (Ire1), a cP-forming endonuclease, is associated with the ER membrane with its C-terminal domain exposed to the cytosol (Urano et al., 2000; Zhang and Kaufman, 2004). While an interaction with 'binding immunoglobulin protein' (BiP), an ER chaperon protein, retains Ire1 as an inactive monomer under normal conditions, ER stress releases BiP, allowing Ire1 to form a homodimer that harbors an active nuclease domain. The activated Ire1 is involved in splicing of HAC1 mRNA (in yeast; $X B P 1$ mRNA in human) by cleaving both $5^{\prime}$ - and $3^{\prime}$-splice sites, in which a $\mathrm{CP}$ is formed at the conserved $3^{\prime}$-terminal $\mathrm{G}$ of $5^{\prime}$-cleavage products (Sidrauski and Walter, 1997; Gonzalez et al., 1999; Shinya et al., 2011) (Figure 3D). From the spliced, mature form of 


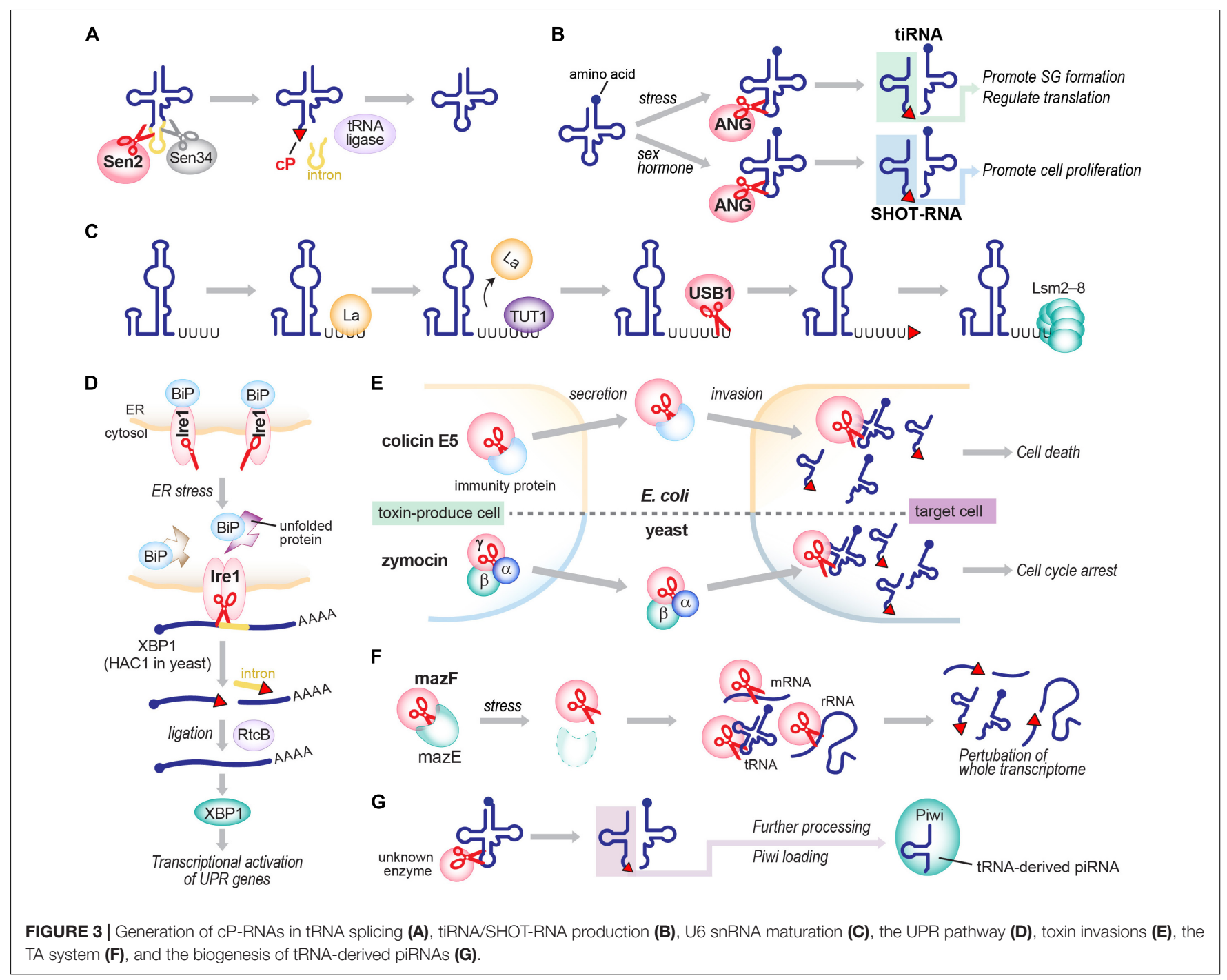

HAC1 mRNA, a basic-region leucine-zipper transcription factor HAC1 is expressed, eventually promoting the transcription of its target genes containing UPR-responsive elements (Sidrauski and Walter, 1997; Urano et al., 2000; Zhang and Kaufman, 2004).

cP-forming endoribonucleases are further found in colicins, toxic proteins that are encoded in plasmid DNAs in some E. coli strains to invade and kill other bacteria (Cascales et al., 2007). Among over 20 colicins identified thus far, colicin E5 and D have been shown to cleave the anticodon-loop of tRNAs and form a cP (Ogawa et al., 1999; Ogawa et al., 2006) (Figure 3E). While endoribonuclease activity of those colicins is masked by immunity proteins in host E. coli, colicin E5 invades other bacteria and cleaves tRNA ${ }^{\text {TyrGUA }}$, tRNA ${ }^{\text {HisGUG }}$, tRNA ${ }^{\text {AsnGUU, }}$ and tRNA ${ }^{\text {AspGUC }}$ between $\mathrm{G}$ at nucleotide position $34\left(\mathrm{G}_{34}\right)$ and $\mathrm{U}_{35}$ (Ogawa et al., 1999, 2006), and colicin D cleaves all four isoacceptors of tRNA ${ }^{\mathrm{Arg}}$ between $\mathrm{A}_{38}$ and $\mathrm{G}_{39} / \mathrm{C}_{39}$ (Tomita et al., 2000), contributing to bacterial lethality.

The E. coli genome also encodes cP-forming endoribonucleases involved in toxin-antitoxin (TA) systems. TA systems involve bacterial stress responses, often considered "suicidal programs," comprising a stable toxin and an unstable antitoxin that neutralizes the cognate toxin in cells (Unterholzner et al., 2013). In the well-studied MazEF system (Figure 3F), toxic endoribonuclease MazF is neutralized by antitoxin MazE under normal conditions, but various stresses, such as nutrient limitation, DNA damage, and antibiotic exposure, degrade MazE and thereby release MazF (Jensen and Gerdes, 1995; Yarmolinsky, 1995; Engelberg-Kulka and Glaser, 1999) which cleaves whole cellular mRNAs to prevent further protein production (Zhang et al., 2003). MazF cleaves the $5^{\prime}$-side of an ACA motif within mRNAs, and forms a cP (Zhang et al., 2003, 2005a; Vesper et al., 2011). Recent reports showed MazF-catalyzed cleavage of $16 \mathrm{~S}$ and $23 \mathrm{~S}$ rRNAs, and some tRNAs such as tRNA ${ }^{\text {LysUUU }}$ (Vesper et al., 2011; Moll and Engelberg-Kulka, 2012; Schifano et al., 2013; Schifano et al., 2014, 2016; Mets et al., 2017), indicating that MazF is a critical suicide factor causing perturbation of the whole cellular transcriptome. The ChpBIK system, another TA system, also uses a cP-forming enzyme as a toxin. When released from antitoxin $\mathrm{ChpBI}$ under stress conditions, toxic endoribonuclease ChpBK cleaves mRNAs at the $5^{\prime}$ - or $3^{\prime}$-side 
of $\mathrm{A}$ in an ACY sequence motif to prevent further protein production (Christensen et al., 2003; Zhang et al., 2005b). The $5^{\prime}$-cleavage products contain.

The genome of some E. coli isolates possesses a prr locus, encoding PrrC endonuclease (also known as anticodon nuclease: ACNase), which is considered to be another bacterial suicide program (Kaufmann, 2000). PrrC activity is usually silenced by interaction with a masking protein, but, upon $\mathrm{T} 4$ phage infection, it forms an ACNase complex and cleaves tRNA ${ }^{\text {LysUUU }}$ between $\mathrm{U}_{33}$ and $\mathrm{U}_{34}$, which serve as a host defense to inhibit translation of T4 proteins (Amitsur et al., 1987; Morad et al., 1993). The $5^{\prime}$-tRNA ${ }^{\text {LysUUU }}$ half resulting from the PrrC cleavage harbors a $\mathrm{CP}$.

cP-forming cytotoxic endoribonucleases are also present in eukaryotes. Zymocin and PaT are toxin complexes secreted by the yeasts Kluyveromyces lactis and Pichia acaciae, respectively, to inhibit the growth of other yeasts (Lu et al., 2005, 2008; Klassen et al., 2008) (Figure 3E). Zymocin is composed of the three subunits; two of them assist target cell binding and invasion, while the remaining $\gamma$-subunit cleaves tRNAs in targeted yeasts (Stark and Boyd, 1986). The $\gamma$-subunit of zymocin recognizes a 5-methoxycarbonylmethyl-2-thiouridine $\left(\mathrm{mcm}^{5} \mathrm{~s}^{2} \mathrm{U}\right)$, a specific modified RNA nucleotide present at np 34 of tRNA ${ }^{\text {GluUUC }}$, tRNA ${ }^{\text {LysUUU }}$, and tRNA ${ }^{\text {GlnUUG }}$, and cleaves between $U_{34}$ and $U_{35}$ of those tRNAs (Lu et al., 2005), leaving a $\mathrm{cP}$ at the ribose of $\mathrm{mcm}^{5} \mathrm{~s}^{2} \mathrm{U}$ in the cleavage products. PaT is a heterodimer composed of PaOrf1, a cell invasion-assisting subunit, and PaOrf2, an endonuclease subunit (McCracken et al., 1994; Klassen et al., 2004). PaOrf2 recognizes 5methoxycarbonylmethyl uridine $\left(\mathrm{mcm}^{5} \mathrm{U}\right)$ and cleaves between $\mathrm{U}_{34}$ and $\mathrm{U}_{35}$ of tRNA ${ }^{\mathrm{Gln} U U G}$, leaving a $\mathrm{cP}$ at the ribose of $\mathrm{mcm}^{5} \mathrm{U}$ in the cleavage product (Klassen et al., 2008; Chakravarty et al., 2014).

cP-forming endoribonucleases are further found in viruses. DNA topoisomerase, encoded in vaccinia virus, belongs to the type IB family of eukaryotic DNA topoisomerases and uniquely harbors endoribonucleolytic activity, which forms a cP end at the cleaved RNAs (Sekiguchi and Shuman, 1997; Shuman, 1998). Analogous to yeast topoisomerase I, which can remove single ribonucleotides in DNA duplexes (Kim et al., 2011), topoisomerase's RNA cleavage activity might be involved in maintaining genome integrity during DNA replication. Replicative nidoviral uridylate-specific endoribonuclease (NendoU), encoded in nidovirus, is also a cP-forming endoribonuclease (Ivanov et al., 2004). While the functional role of the endoribonuclease activity in virus infection and replication is not fully understood, NendoU preferentially targets dsRNA and cleaves the $5^{\prime}$-side of uridine in $\mathrm{G}-\mathrm{U}$ or G-U-U sequence to generate cP-RNAs (Ivanov et al., 2004).

\section{Ribozymes}

Ribozymes are another cP-yielding biocatalyst. Among several distinct classes of ribozymes, a class of small, self-cleaving ribozymes is known to generate cPs (Scott and Klug, 1996; Doherty and Doudna, 2001; Serganov and Patel, 2007). Small self-cleaving ribozymes are widely found in bacterial, plant, and mammalian genomes, and are involved in gene controls and expressions (Shih and Been, 2002; Serganov and Patel, 2007). Out of 11 identified ribozymes in this class, 10 have been shown to form $\mathrm{cP}$ ends as a result of their cleavage of RNAs (Saville and Collins, 1990; Scott and Klug, 1996; Winkler et al., 2004; SalehiAshtiani et al., 2006; Roth et al., 2014; Harris et al., 2015; Li et al., 2015; Weinberg et al., 2015). In the case of the hepatitis delta virus (HDV) ribozyme, the 85-nt minimal self-cleavage domain cleaves between $U_{-1}$ and $G_{1}$ (Shih and Been, 2002; Puerta-Fernandez et al., 2003). While $\mathrm{C}_{75}$ is suggested to act as a general acid catalyst by donating a proton from its $\mathrm{N} 3$ in the pyrimidine ring to a leaving group, several different molecules have been proposed as potential base catalysts: water or hydroxide from the solvent, water molecules coordinated to the $\mathrm{Mg}^{2+}$, or $2^{\prime}-\mathrm{OH}$ of $\mathrm{G}_{27}$ positioned closely adjacent to the catalytic site (Ward et al., 2014).

\section{Enzymes That Act Directly on the $3^{\prime}$-End of RNAs}

There are two protein catalysts that have been reported to form a $\mathrm{cP}$ by a distinct molecular mechanism from transesterification during RNA cleavage. As described above, RtcA can catalyze de novo $\mathrm{CP}$ formation by directly acting on the $3^{\prime}$-end of RNAs (Genschik et al., 1997, 1998; Billy et al., 2000; Filipowicz, 2016). Although endogenous RNA target of RtcA is unknown, in the E. coli genome, $r t c A$ and an RNA ligase $r t c B$ form an $r t c B A$ operon, which is implicated in RNA repair pathway (Das and Shuman, 2013a; Burroughs and Aravind, 2016). Archaeal thermophilic RNA ligase from Methanobacterium thermoautotrophicum, MthRnl, is the other enzyme which can also catalyze de novo cP formation (Zhelkovsky and McReynolds, 2014; Yoshinari et al., 2017). While MthRnl can ligate 5' $-\mathrm{P}$ and $3^{\prime}-\mathrm{OH}$ ends of RNAs (Torchia et al., 2008), when substrate RNAs contain a $3^{\prime}-\mathrm{P}$, MthRnl coverts it to a $3^{\prime}-\mathrm{cP}$ by a similar mechanism with RtcA (Zhelkovsky and McReynolds, 2014). In addition, MthRnl possesses the $3^{\prime}$-deadenylation activity which can remove a $3^{\prime}$-terminal adenosine with an $\mathrm{OH}$ end and form a cP (Yoshinari et al., 2017). Endogenous RNA target of MthRnl is unknown.

\section{BIOLOGICAL SIGNIFICANCE OF CP FORMATION AND CP-RNA EXPRESSION}

What is the significance of $\mathrm{cP}$ formation in RNAs? It has been shown that $\mathrm{CP}$ formation in U6 snRNA regulates RNA interaction with protein factors. While nascent U6 snRNA containing $3^{\prime}-\mathrm{OH}$ end is bound by La protein (Maraia and Intine, 2002; Maraia and Bayfield, 2006), cP formation of mature U6 snRNA promotes interaction with Lsm2-8 complexes (Khusial et al., 2005; Licht et al., 2008) (Figure 3C). The affinity of the cP-containing RNA to Lsm2-8 is higher than $3^{\prime}-\mathrm{OH}$-containing RNA, and the interaction of $\mathrm{La} / 3^{\prime}-\mathrm{OH}$ and $\mathrm{Lsm} 2-8 / \mathrm{cP}$ is mutually exclusive: even when both La and Lsm2-8 exist in the reaction solution, RNA with $3^{\prime}-\mathrm{OH}$ or with $\mathrm{cP}$ only binds to La or Lsm2-8, respectively (Licht et al., 2008). cP formation is, therefore, a critical factor for forming functional spliceosome complexes with Lsm2-8 (Didychuk et al., 2018). Although this is the only proven 
example of the cP-regulated formation of RNA-protein complex, $\mathrm{cP}$ formation in other $\mathrm{CP}-\mathrm{RNAs}$ may modulate RNA interaction with protein factors.

RNA ligation reaction can depend on a $\mathrm{cP}$ in a substrate RNA. In tRNA splicing, Sen2-mediated cleavage forms a $3^{\prime}$ terminal $\mathrm{cP}$ in $5^{\prime}$-exons, which is then ligated to the $5^{\prime}-\mathrm{OH}$ end of $3^{\prime}$-exons by tRNA ligase (Popow et al., 2012; Yoshihisa, 2014) (Figure 3A). In Arabidopsis thaliana, the tRNA ligase AtRNL is able to ligate $\mathrm{cP}$ ends to $3^{\prime}$-exons but cannot use $3^{\prime}$-P ends as its ligation substrate (Schutz et al., 2010; Tanaka et al., 2011a). This cP-specific ligation activity was also observed in wheat germ extract (Konarska et al., 1982). In this plant ligation process, $\mathrm{cP}$ ends of $5^{\prime}$-exons are first converted to $2^{\prime}$-P and $3^{\prime}-\mathrm{OH} .5^{\prime}$ $\mathrm{OH}$ ends of $3^{\prime}$-exons are phosphorylated, followed by ligation to $3^{\prime}$-OH of $5^{\prime}$-exons (Popow et al., 2012; Yoshihisa, 2014). Other organisms employ distinct molecular mechanisms in ligation of cP-containing $5^{\prime}$-exons to $3^{\prime}$-exons in tRNA splicing (Popow et al., 2012; Yoshihisa, 2014). In humans, RtcB was identified as a tRNA ligase (Popow et al., 2011). Experiments using lysates and RtcB immunoprecipitates from HeLa cells suggest that human RtcB prefers $\mathrm{cP}$ and $5^{\prime}-\mathrm{OH}$ for ligation (Filipowicz et al., 1983; Popow et al., 2011). However, whether the substrate specificity extends to $3^{\prime}-\mathrm{P}$ and $5^{\prime}-\mathrm{OH}$ containing RNA still awaits analysis using a recombinant human tRNA ligase complex. In mammals, RtcB is involved in splicing of XBP1 mRNA in the UPR pathway (Filipowicz, 2014; Jurkin et al., 2014; Lu et al., 2014) (Figure 3D). E. coli $\mathrm{RtcB}$ is also able to ligate $\mathrm{cP}$ and $5^{\prime}-\mathrm{OH}$, as well as $3^{\prime}$ $\mathrm{P}$ and $5^{\prime}-\mathrm{OH}$ (Tanaka and Shuman, 2011; Tanaka et al., 2011b). In the ligation, $\mathrm{cP}$ is first converted to $3^{\prime}-\mathrm{P}$, then ligated to $5^{\prime}-\mathrm{OH}$ (Tanaka et al., 2011a). E. coli RtcB can catalyze the religation of $16 \mathrm{~S}$ rRNA at the site cleaved by stress-induced MazF activity, which generates full-length $16 \mathrm{~S}$ rRNA and contributes to restoration from the stress conditions (Temmel et al., 2017).

Besides influencing interaction and activity of proteins, $\mathrm{cP}$ formation may play a role in stabilizing RNA molecules by protecting them from degradation. Ehrlich exoribonuclease extracted from Ehrlich ascites cells and various mouse tissues, later defined as exoribonuclease II, was shown to degrade singlestranded RNAs with $3^{\prime}$-OH ends more rapidly than those with $\mathrm{cP}$ and $3^{\prime}$-P ends (Sporn et al., 1969), suggesting that $\mathrm{cP}$ formation is advantageous for RNA molecules to exist stably in cells. In contrast, because RNAs with 3'-P ends are more rapidly degraded by the exosome complex exoribonuclease, Rrp44, than those with $3^{\prime}-\mathrm{OH}$ ends (Zinder et al., 2016), cP formation could also negatively impact the stability of cP-RNAs. Thus, a cP structure might be able to regulate RNA stability in both directions by affecting degradation activity of nucleases or modulating RNAprotein interactions. Further study is required to shed more light on the potential function of $\mathrm{cP}$ formation in RNA stability.

The above described advantages of $\mathrm{cP}$ formation may, in turn, suggest the biological significance of cellular cP-RNA expression. While the functional significance of U6 snRNA, which belongs to cP-RNAs, or tRNAs and rRNAs, whose biogenesis is intermediated by cP-RNAs, have been apparent for a long time, previously uncharacterized cP-RNAs are now being demonstrated as functional molecules which play important roles in various biological processes. Representative examples of such functional cP-RNAs include the $5^{\prime}$-tRNA half molecules. In mammalian cells, various stress stimuli trigger ANG-mediated tRNA cleavage to produce functional tRNA halves, termed tRNA-derived stress-induced RNAs (tiRNAs) (Fu et al., 2009; Yamasaki et al., 2009) (Figure 3B). 5' -tiRNAs, corresponding to $5^{\prime}$-tRNA halves, have been shown as functional molecules that can promote formation of stress granules and regulate translation via YB-1 protein-involved pathway (Emara et al., 2010; Ivanov et al., 2011, 2014; Lyons et al., 2016).

ANG-mediated tRNA cleavage is also promoted by sex hormone signaling pathways in hormone dependent breast and prostate cancer cells, generating a distinct class of tRNA halves termed sex hormone-dependent tRNA-derived RNAs (SHOT-RNAs) (Honda et al., 2015; Honda and Kirino, 2016) (Figure 3B). 5'-SHOT-RNAs, belonging to cP-RNAs, promote cell proliferation. The expression levels of SHOT-RNAs in tissues and serum of prostate cancer patients have been shown to be associated with pathological and prognostic parameters, suggesting the use of SHOT-RNAs as potential diagnostic biomarkers (Zhao et al., 2018). In terms of diseases, many different $A N G$ gene mutations have been identified in patients with amyotrophic lateral sclerosis (ALS) and Parkinson's disease (Tello-Montoliu et al., 2006; Gao and Xu, 2008), implying that ANG-catalyzed production of tRNA halves could be involved in the pathogenesis of these neurodegenerative disorders (Thiyagarajan et al., 2012). Indeed, accumulation of tRNA halves contributes to the pathogenesis of a syndromic form of intellectual disability and Dubowitz-like syndrome (Blanco et al., 2014).

cP-RNAs can also function as direct precursors for shorter functional RNAs. In B. mori germ cells, some abundant species of Piwi-interacting RNAs (piRNAs), a germline-specific class of small regulatory RNAs, are produced directly from $\mathrm{cP}$-containing $5^{\prime}$-tRNA halves (Honda et al., 2017) (Figure 3G). Although many microRNAs (miRNAs) are derived from tRNAs (Shigematsu and Kirino, 2015; Telonis et al., 2015), whether the tRNA-derived miRNAs are also generated from cP-containing tRNA halves has not been examined yet. Further research may reveal more evidence of cP-RNA uses as direct precursors for functional RNAs.

\section{SPECIFIC SEQUENCING AND QUANTIFICATION OF cP-RNAS}

To further expand cP-RNA research, it is imperative to capture cP-RNA expression profiles accurately, which is not possible using standard RNA-seq methods. Specific cP-RNA sequencing can be achieved by cP-RNA-seq (Honda et al., 2015, 2016) which takes advantage of distinct properties of two well-used enzymes, T4 polynucleotide kinase (T4 PNK) and a phosphatase such as calf intestinal phosphatase (CIP). T4 PNK has $3^{\prime}$-terminal phosphatase activity that removes both a $\mathrm{P}$ and $\mathrm{cP}$ from the $3^{\prime}$ end of RNAs (Amitsur et al., 1987; Das and Shuman, 2013b), whereas CIP removes only a P but not a cP. In cP-RNA-seq, RNAs are first treated with CIP to remove a $\mathrm{P}$, followed by periodate oxidization. Because the oxidation cleaves the $3^{\prime}$-end 


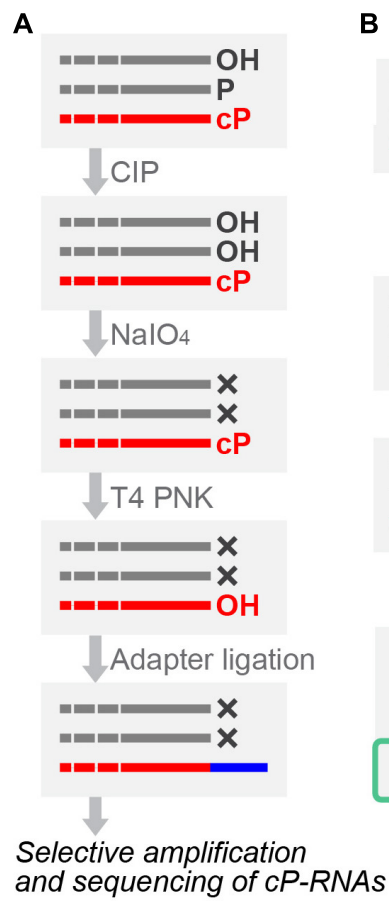

A and sequencing of $C P-R N A s$

B

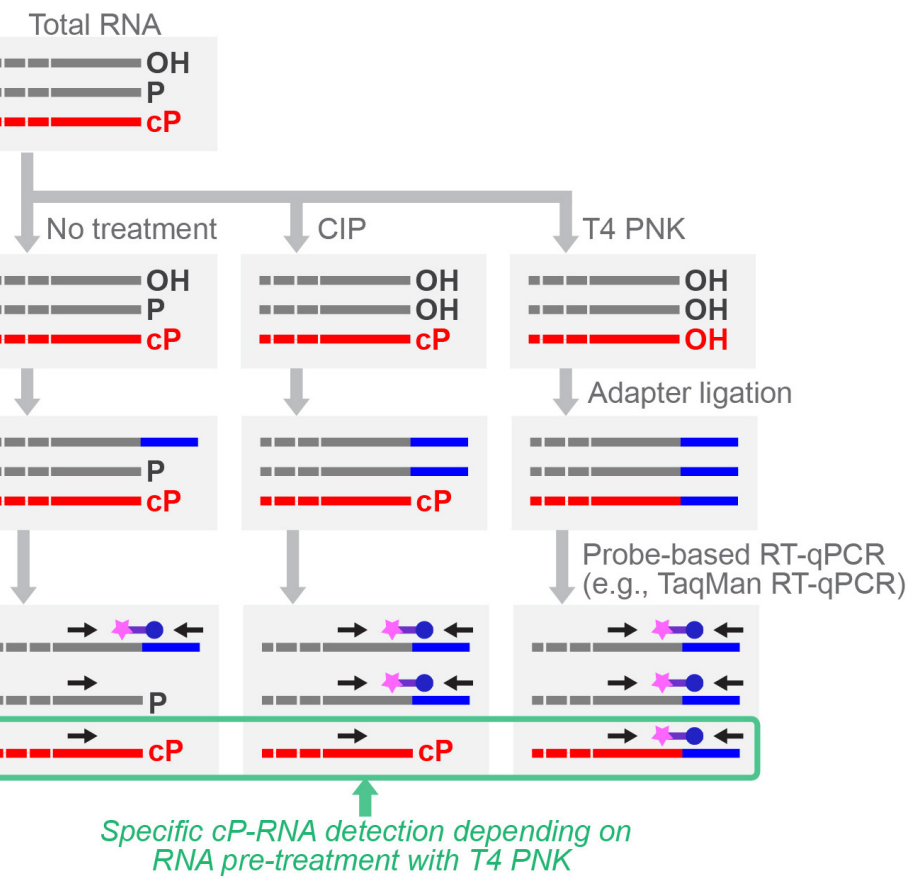

FIGURE 4 | Schematic representation of cP-RNA-seq (A) and probe-based RT-qPCR (B) for specific cP-RNA analyses.

of all RNAs other than cP-RNAs, subsequent cP removal, adapter ligation, and cDNA amplification steps are exclusively applied to cP-RNAs, leading to selective amplification and sequencing of cPRNAs (Honda et al., 2015, 2016) (Figure 4A). cP-RNA-seq only requires commercially available enzymes and reagents, which is an advantage of the method. As a limitation of the method, RNAs lacking a $2^{\prime}, 3^{\prime}$-diol structure of ribose, such as plant miRNAs and animal piRNAs that contain $2^{\prime}$-O-methyl ribose modification (Yang et al., 2006; Kirino and Mourelatos, 2007; Ohara et al., 2007), can also be amplified despite the absence of a cP, because those RNAs would be resistant to periodate oxidation. This point should always be remembered especially when 20-30-nt small RNAs are used for the method. Thus far, cP-RNA-seq has been applied only to the two cell lines, human BT-474 breast cancer cells and B. mori BmN4 cells (Honda et al., 2015, 2017). Although high mapping ratio of the obtained reads to tRNA sequences showed the specificity and credibility of the method, both of the studies narrowly focused on short RNA fraction containing tRNA haves. Further application of the method to broader RNA populations will enable more global identification of cP-RNA species.

As an alternative method, Arabidopsis tRNA ligase AtRNL can be used for specific cP-RNA sequencing (Schutz et al., 2010). Because its ligation activity is specific to a $\mathrm{cP}$ but not to a $3^{\prime}$-P and $3^{\prime}-\mathrm{OH}$, AtRNL selectively ligates a $3^{\prime}$-adapter to cP-RNAs among all RNA species. After the ligation, for efficient reverse transcription, a $2^{\prime}-\mathrm{P}$ formed at the substrateadapter junction should be removed by $2^{\prime}$-phosphotransferase treatment. Therefore, two specific recombinant proteins, AtRNL and Saccharomyces cerevisiae $2^{\prime}$-phosphotransferase Tpt1, were purified and used in the method (Schutz et al., 2010). Application of the method to human brain total RNA identified numerous reads of cP-RNAs containing U6 snRNA. The $3^{\prime}$-ends of $\sim 90 \%$ of the U6 snRNA reads were identified as a consistent, mature form, validating the specificity and credibility of the method. Considering the ligation activity for cP-RNAs, RtcB can also be used for cP-RNA sequencing (Donovan et al., 2017). Because RtcB can ligate $3^{\prime}-\mathrm{P}$ ends, as well as cP ends, a phosphatase treatment to remove $3^{\prime}$-P prior to RtcB-mediated $3^{\prime}$-adaptor ligation would be required for specific capture of $\mathrm{cP}-\mathrm{RNAs}$.

After cP-RNA sequencing, amplification and quantification of the representative identified cP-RNA species are necessary to validate their expression and analyze whether a $\mathrm{cP}$ end is the major $3^{\prime}$-end form of the identified sequences. Standard RT-qPCR, amplifying internal sequences of targeted RNAs, is inappropriate for specific amplification of cP-RNAs because it cannot distinguish between cP-RNAs and RNAs with other terminal states. To specifically analyze cP-RNAs, RNAs treated with T4 PNK or CIP can be subjected to $3^{\prime}$-adapter ligation, followed by TaqMan RT-qPCR targeting $3^{\prime}$-adapter-RNA ligation products (Honda and Kirino, 2015; Honda et al., 2015, 2017; Shigematsu et al., 2018; Zhao et al., 2018) (Figure 4B). The dependency of amplification signals on RNA treatment with T4 PNK, but not with CIP, allows researchers to confirm that the detected signals are derived from cP-RNAs because they should be ligated to a $3^{\prime}$-adapter only after $\mathrm{cP}$ removal by $\mathrm{T} 4$ $\mathrm{PNK}$ treatment. As an alternative method for analyzing $\mathrm{cP}$ ends, T4 PNK- or CIP-treated RNAs can be subjected to a poly (A) polymerase reaction which is able to add poly (A) tails to $3^{\prime}-\mathrm{OH}$ ends, but not to cP ends (Zaug et al., 1996). Moreover, northern 
blot can be used to observe slight differences in band mobility between CP-RNAs and RNAs with other terminal states (Honda et al., 2015, 2016).

\section{FUTURE PERSPECTIVES}

Despite the findings described in this review, current information regarding cellular expression profiles of cP-RNAs is very limited and fragmented. Although increasing accumulation of RNA-seq data has accelerated the comparative analyses of transcriptomes and, therefore, been critical to identifying significant RNA species in biological phenomena and diseases, the "invisibility" of cPRNA expression in RNA-seq data makes cP-RNA research be still at an initial stage. The immediate future focus should be on capturing the comprehensive repertoire of cP-RNAs expressed in different tissues and cells by using the above described specific sequencing methods. Given that cP-RNAs are expressed as functional molecules, capturing the entire cP-RNA repertoire would broaden the catalog of functional non-coding RNAs and could reveal significant biological events that have been eluding standard RNA-seq. Besides cP-RNA expression, molecular mechanisms behind cP-RNA biogenesis and function still remain elusive. Presumably, not all cP-RNA-producing enzymes have been identified and characterized to date. Because determining cP-RNA-generating enzymes only by their aminoacid sequences and protein motifs is impossible, discovering

\section{REFERENCES}

Abelson, J., Trotta, C. R., and Li, H. (1998). tRNA splicing. J. Biol. Chem. 273, 12685-12688. doi: 10.1074/jbc.273.21.12685

Acharya, K. R., Shapiro, R., Allen, S. C., Riordan, J. F., and Vallee, B. L. (1994). Crystal structure of human angiogenin reveals the structural basis for its functional divergence from ribonuclease. Proc. Natl. Acad. Sci. U.S.A. 91, 2915-2919. doi: 10.1073/pnas.91.8.2915

Amitsur, M., Levitz, R., and Kaufmann, G. (1987). Bacteriophage T4 anticodon nuclease, polynucleotide kinase and RNA ligase reprocess the host lysine tRNA. EMBO J. 6, 2499-2503. doi: 10.1002/j.1460-2075.1987.tb02532.x

Anantharaman, V., Makarova, K. S., Burroughs, A. M., Koonin, E. V., and Aravind, L. (2013). Comprehensive analysis of the HEPN superfamily: identification of novel roles in intra-genomic conflicts, defense, pathogenesis and RNA processing. Biol. Direct 8:15. doi: 10.1186/1745-6150-8-151745-6150$8-15$

Bartlett, G. J., Porter, C. T., Borkakoti, N., and Thornton, J. M. (2002). Analysis of catalytic residues in enzyme active sites. J. Mol. Biol. 324, 105-121. doi: 10.1016/S0022-2836(02)01036-7

Bierhals, T., Korenke, G. C., Uyanik, G., and Kutsche, K. (2013). Pontocerebellar hypoplasia type 2 and TSEN2: review of the literature and two novel mutations. Eur. J. Med. Genet. 56, 325-330. doi: 10.1016/j.ejmg.2013.03. 009S1769-7212(13)00081-5

Billy, E., Wegierski, T., Nasr, F., and Filipowicz, W. (2000). Rcllp, the yeast protein similar to the RNA $3^{\prime}$-phosphate cyclase, associates with U3 snoRNP and is required for $18 \mathrm{~S}$ rRNA biogenesis. EMBO J. 19, 2115-2126. doi: 10.1093/emboj/ 19.9.2115

Blanco, S., Dietmann, S., Flores, J. V., Hussain, S., Kutter, C., Humphreys, P., et al. (2014). Aberrant methylation of tRNAs links cellular stress to neurodevelopmental disorders. EMBO J. 33, 2020-2039. doi: 10.15252/embj. 201489282embj.201489282

Budde, B. S., Namavar, Y., Barth, P. G., Poll-The, B. T., Nurnberg, G., Becker, C., et al. (2008). tRNA splicing endonuclease mutations cause pontocerebellar hypoplasia. Nat. Genet. 40, 1113-1118. doi: 10.1038/ng.204ng.204 novel cP-RNA-generating enzymes will rely on detailed structural and biochemical characterizations of each enzyme. Given the already-proven biological roles of $\mathrm{cP}$ formation and cP-RNA expression, it is not surprising that $\mathrm{cP}-\mathrm{RNAs}$ are involved in a wide range of biological processes. Considering the "hidden" nature of cP-RNAs in conventional RNA-seq data, further research efforts to characterize cP-RNAs would likely clarify substantially greater biological significance of cP-RNAs, which will advance our understanding of the expanding realm of noncoding RNA molecules.

\section{AUTHOR CONTRIBUTIONS}

MS and YK conceptualized the theme and wrote the review with substantial help by TK in compiling reference papers. All authors reviewed and approved the final manuscript.

\section{FUNDING}

Work in the lab on this topic has been supported by the National Institutes of Health Grant (GM106047 and AI130496 to YK), American Cancer Society Research Scholar Grant (RSG-17-05901-RMC to YK), the W. W. Smith Charitable Trust Grant (C1608 to YK), and a Japan Society for the Promotion of Science Postdoctoral Fellowship for Research Abroad (to MS).

Burroughs, A. M., and Aravind, L. (2016). RNA damage in biological conflicts and the diversity of responding RNA repair systems. Nucleic Acids Res. 44, 8525-8555. doi: 10.1093/nar/gkw722

Cascales, E., Buchanan, S. K., Duche, D., Kleanthous, C., Lloubes, R., Postle, K., et al. (2007). Colicin biology. Microbiol. Mol. Biol. Rev. 71, 158-229. doi: 10.1128/MMBR.00036-06

Castle, C. D., Cassimere, E. K., Lee, J., and Denicourt, C. (2010). Las1L is a nucleolar protein required for cell proliferation and ribosome biogenesis. Mol. Cell Biol. 30, 4404-4414. doi: 10.1128/MCB.00358-10

Chakravarty, A. K., Smith, P., Jalan, R., and Shuman, S. (2014). Structure, mechanism, and specificity of a eukaryal tRNA restriction enzyme involved in self-nonself discrimination. Cell Rep. 7, 339-347. doi: 10.1016/j.celrep.2014.03. 034

Chan, P. P., and Lowe, T. M. (2016). GtRNAdb 2.0: an expanded database of transfer RNA genes identified in complete and draft genomes. Nucleic Acids Res. 44, D184-D189. doi: 10.1093/nar/gkv1309

Cho, S., and Zhang, J. (2006). Ancient expansion of the ribonuclease A superfamily revealed by genomic analysis of placental and marsupial mammals. Gene 373, 116-125. doi: 10.1016/j.gene.2006.01.018

Christensen, S. K., Pedersen, K., Hansen, F. G., and Gerdes, K. (2003). Toxinantitoxin loci as stress-response-elements: ChpAK/MazF and ChpBK cleave translated RNAs and are counteracted by tmRNA. J. Mol. Biol. 332, 809-819. doi: $10.1016 / \mathrm{S} 0022-2836(03) 00922-7$

Cuchillo, C. M., Nogues, M. V., and Raines, R. T. (2011). Bovine pancreatic ribonuclease: fifty years of the first enzymatic reaction mechanism. Biochemistry 50, 7835-7841. doi: 10.1021/bi201075b

Cuchillo, C. M., Vilanova, M., and Nogues, V. (1997). "'Pancreatic ribonucleases," in Ribonucleases: Structures and Functions, eds G. D. Alessio and J. F. Riordan (Cambridge, MA: Academic Press), 272-297.

Das, U., and Shuman, S. (2013a). 2'-Phosphate cyclase activity of RtcA: a potential rationale for the operon organization of RtcA with an RNA repair ligase RtcB in Escherichia coli and other bacterial taxa. RNA 19, 1355-1362. doi: 10.1261/rna. 039917.113 
Das, U., and Shuman, S. (2013b). Mechanism of RNA $2^{\prime}, 3^{\prime}$-cyclic phosphate end healing by T4 polynucleotide kinase-phosphatase. Nucleic Acids Res. 41, 355-365. doi: 10.1093/nar/gks977

Didychuk, A. L., Butcher, S. E., and Brow, D. A. (2018). The life of U6 small nuclear RNA, from cradle to grave. RNA 24, 437-460. doi: 10.1261/rna.065136.117

Didychuk, A. L., Montemayor, E. J., Carrocci, T. J., DeLaitsch, A. T., Lucarelli, S. E., Westler, W. M., et al. (2017). Usb1 controls U6 snRNP assembly through evolutionarily divergent cyclic phosphodiesterase activities. Nat. Commun. 8:497. doi: 10.1038/s41467-017-00484-w

Doherty, E. A., and Doudna, J. A. (2001). Ribozyme structures and mechanisms. Annu. Rev. Biophys. Biomol. Struct. 30, 457-475. doi: 10.1146/annurev.biophys. 30.1.457

Donovan, J., Rath, S., Kolet-Mandrikov, D., and Korennykh, A. (2017). Rapid RNase L-driven arrest of protein synthesis in the dsRNA response without degradation of translation machinery. RNA 23, 1660-1671. doi: 10.1261/rna. 062000.117

Dyer, K. D., and Rosenberg, H. F. (2006). The RNase a superfamily: generation of diversity and innate host defense. Mol. Divers. 10, 585-597. doi: 10.1007/ s11030-006-9028-2

Emara, M. M., Ivanov, P., Hickman, T., Dawra, N., Tisdale, S., Kedersha, N., et al. (2010). Angiogenin-induced tRNA-derived stress-induced RNAs promote stress-induced stress granule assembly. J. Biol. Chem. 285, 10959-10968. doi: 10.1074/jbc.M109.077560

Engelberg-Kulka, H., and Glaser, G. (1999). Addiction modules and programmed cell death and antideath in bacterial cultures. Annu. Rev. Microbiol. 53, 43-70. doi: 10.1146/annurev.micro.53.1.43

Fabian, H., and Mantsch, H. H. (1995). Ribonuclease A revisited: infrared spectroscopic evidence for lack of native-like secondary structures in the thermally denatured state. Biochemistry 34, 13651-13655. doi: 10.1021/ bi00041a046

Fett, J. W., Strydom, D. J., Lobb, R. R., Alderman, E. M., Bethune, J. L., Riordan, J. F., et al. (1985). Isolation and characterization of angiogenin, an angiogenic protein from human carcinoma cells. Biochemistry 24, 5480-5486. doi: 10.1021/ bi00341a030

Filipowicz, W. (2014). Making ends meet: a role of RNA ligase RTCB in unfolded protein response. EMBO J. 33, 2887-2889. doi: 10.15252/embj.201490425

Filipowicz, W. (2016). RNA $3^{\prime}$-terminal phosphate cyclases and cyclase-like proteins. Postepy Biochem. 62, 327-334.

Filipowicz, W., Konarska, M., Gross, H. J., and Shatkin, A. J. (1983). RNA 3'terminal phosphate cyclase activity and RNA ligation in HeLa cell extract. Nucleic Acids Res. 11, 1405-1418. doi: 10.1093/nar/11.5.1405

Fu, H., Feng, J., Liu, Q., Sun, F., Tie, Y., Zhu, J., et al. (2009). Stress induces tRNA cleavage by angiogenin in mammalian cells. FEBS Lett. 583, 437-442. doi: 10.1016/j.febslet.2008.12.043

Gao, X., and Xu, Z. (2008). Mechanisms of action of angiogenin. Acta Biochim. Biophys. Sin. 40, 619-624. doi: 10.1111/j.1745-7270.2008.00442.x

Gasse, L., Flemming, D., and Hurt, E. (2015). Coordinated ribosomal ITS2 RNA processing by the las 1 complex integrating endonuclease, polynucleotide kinase, and exonuclease activities. Mol. Cell 60, 808-815. doi: 10.1016/j.molcel. 2015.10.021

Genschik, P., Billy, E., Swianiewicz, M., and Filipowicz, W. (1997). The human RNA $3^{\prime}$-terminal phosphate cyclase is a member of a new family of proteins conserved in Eucarya, Bacteria and Archaea. EMBO J. 16, 2955-2967. doi: 10.1093/emboj/16.10.2955

Genschik, P., Drabikowski, K., and Filipowicz, W. (1998). Characterization of the Escherichia coli RNA 3'-terminal phosphate cyclase and its sigma54regulated operon. J. Biol. Chem. 273, 25516-25526. doi: 10.1074/jbc.273.39. 25516

Gerstberger, S., Meyer, C., Benjamin-Hong, S., Rodriguez, J., Briskin, D., Bognanni, C., et al. (2017). The conserved RNA exonuclease Rexo5 is required for $3^{\prime}$ end maturation of $28 \mathrm{~S}$ rRNA, 5S rRNA, and snoRNAs. Cell Rep. 21, 758-772. doi: 10.1016/j.celrep.2017.09.067

Gonzalez, T. N., Sidrauski, C., Dorfler, S., and Walter, P. (1999). Mechanism of non-spliceosomal mRNA splicing in the unfolded protein response pathway. EMBO J. 18, 3119-3132. doi: 10.1093/emboj/18.11.3119

Harper, J. W., and Vallee, B. L. (1989). A covalent angiogenin/ribonuclease hybrid with a fourth disulfide bond generated by regional mutagenesis. Biochemistry 28, 1875-1884. doi: 10.1021/bi00430a067
Harris, K. A., Lunse, C. E., Li, S., Brewer, K. I., and Breaker, R. R. (2015). Biochemical analysis of pistol self-cleaving ribozymes. RNA 21, 1852-1858. doi: 10.1261/rna.052514.115

Henras, A. K., Plisson-Chastang, C., O’Donohue, M. F., Chakraborty, A., and Gleizes, P. E. (2015). An overview of pre-ribosomal RNA processing in eukaryotes. Wiley Interdiscip. Rev. RNA 6, 225-242. doi: 10.1002/wrna.1269

Hilcenko, C., Simpson, P. J., Finch, A. J., Bowler, F. R., Churcher, M. J., Jin, L., et al. (2013). Aberrant $3^{\prime}$ oligoadenylation of spliceosomal U6 small nuclear RNA in poikiloderma with neutropenia. Blood 121, 1028-1038. doi: 10.1182/ blood-2012-10-461491

Holloway, D. E., Chavali, G. B., Hares, M. C., Baker, M. D., Subbarao, G. V., Shapiro, R., et al. (2004). Crystallographic studies on structural features that determine the enzymatic specificity and potency of human angiogenin: Thr44, Thr80, and residues 38-41. Biochemistry 43, 1230-1241. doi: 10.1021/bi035654+

Honda, S., Kawamura, T., Loher, P., Morichika, K., Rigoutsos, I., and Kirino, Y. (2017). The biogenesis pathway of tRNA-derived piRNAs in Bombyx germ cells. Nucleic Acids Res. 45, 9108-9120. doi: 10.1093/nar/gkx537

Honda, S., and Kirino, Y. (2015). Dumbbell-PCR: a method to quantify specific small RNA variants with a single nucleotide resolution at terminal sequences. Nucleic Acids Res. 43:e77. doi: 10.1093/nar/gkv218

Honda, S., and Kirino, Y. (2016). SHOT-RNAs: a novel class of tRNA-derived functional RNAs expressed in hormone-dependent cancers. Mol. Cell. Oncol. 3:e1079672. doi: 10.1080/23723556.2015.1079672

Honda, S., Loher, P., Shigematsu, M., Palazzo, J. P., Suzuki, R., Imoto, I., et al. (2015). Sex hormone-dependent tRNA halves enhance cell proliferation in breast and prostate cancers. Proc. Natl. Acad. Sci. U.S.A. 112, E3816-E3825. doi: 10.1073/pnas.1510077112

Honda, S., Morichika, K., and Kirino, Y. (2016). Selective amplification and sequencing of cyclic phosphate-containing RNAs by the cP-RNA-seq method. Nat. Protoc. 11, 476-489. doi: 10.1038/nprot.2016.025

Hopper, A. K., and Phizicky, E. M. (2003). tRNA transfers to the limelight. Genes Dev. 17, 162-180. doi: 10.1101/gad.1049103

Inoue-Ito, S., Yajima, S., Fushinobu, S., Nakamura, S., Ogawa, T., Hidaka, M., et al. (2012). Identification of the catalytic residues of sequence-specific and histidine-free ribonuclease colicin E5. J. Biochem. 152, 365-372. doi: 10.1093/ $\mathrm{jb} / \mathrm{mvs} 077$

Irie, M. (1997). “"RNase T1/RNase T2 family RNases," in Ribonucleases: Structures and Functions, eds G. D. Alessio and J. F. Riordan (Cambridge, MA: Academic Press), 101-124.

Ivanov, K. A., Hertzig, T., Rozanov, M., Bayer, S., Thiel, V., Gorbalenya, A. E., et al. (2004). Major genetic marker of nidoviruses encodes a replicative endoribonuclease. Proc. Natl. Acad. Sci. U.S.A. 101, 12694-12699. doi: 10.1073/ pnas.0403127101

Ivanov, P., Emara, M. M., Villén, J., Gygi, S. P., and Anderson, P. (2011). Angiogenin-induced tRNA fragments inhibit translation initiation. Mol. Cell 43, 613-623. doi: 10.1016/j.molcel.2011.06.022

Ivanov, P., O’Day, E., Emara, M. M., Wagner, G., Lieberman, J., and Anderson, P. (2014). G-quadruplex structures contribute to the neuroprotective effects of angiogenin-induced tRNA fragments. Proc. Natl. Acad. Sci. U.S.A. 111, 1820118206. doi: 10.1073/pnas.1407361111

Jensen, R. B., and Gerdes, K. (1995). Programmed cell death in bacteria: proteic plasmid stabilization systems. Mol. Microbiol. 17, 205-210. doi: 10.1111/j.13652958.1995.mmi_17020205.x

Jurkin, J., Henkel, T., Nielsen, A. F., Minnich, M., Popow, J., Kaufmann, T., et al. (2014). The mammalian tRNA ligase complex mediates splicing of XBP1 mRNA and controls antibody secretion in plasma cells. EMBO J. 33, 2922-2936. doi: 10.15252/embj.201490332

Kaufmann, G. (2000). Anticodon nucleases. Trends Biochem. Sci. 25, 70-74. doi: 10.1016/S0968-0004(99)01525-X

Khusial, P., Plaag, R., and Zieve, G. W. (2005). LSm proteins form heptameric rings that bind to RNA via repeating motifs. Trends Biochem. Sci. 30, 522-528. doi: 10.1016/j.tibs.2005.07.006

Kim, N., Huang, S. N., Williams, J. S., Li, Y. C., Clark, A. B., Cho, J. E., et al. (2011). Mutagenic processing of ribonucleotides in DNA by yeast topoisomerase I. Science 332, 1561-1564. doi: 10.1126/science.1205016

Kirino, Y., and Mourelatos, Z. (2007). Mouse Piwi-interacting RNAs are 2'-Omethylated at their $3^{\prime}$ termini. Nat. Struct. Mol. Biol. 14, 347-348. doi: 10.1038/ nsmb1218 
Klassen, R., Paluszynski, J. P., Wemhoff, S., Pfeiffer, A., Fricke, J., and Meinhardt, F. (2008). The primary target of the killer toxin from Pichia acaciae is tRNA(Gln). Mol. Microbiol. 69, 681-697. doi: 10.1111/j.1365-2958.2008.06319.x

Klassen, R., Teichert, S., and Meinhardt, F. (2004). Novel yeast killer toxins provoke S-phase arrest and DNA damage checkpoint activation. Mol. Microbiol. 53, 263-273. doi: 10.1111/j.1365-2958.2004.04119.x

Konarska, M., Filipowicz, W., and Gross, H. J. (1982). RNA ligation via $2^{\prime}$ phosphomonoester, $3^{\prime} 5^{\prime}$-phosphodiester linkage: requirement of $2^{\prime}, 3^{\prime}$-cyclic phosphate termini and involvement of a $5^{\prime}$-hydroxyl polynucleotide kinase. Proc. Natl. Acad. Sci. U.S.A. 79, 1474-1478. doi: 10.1073/pnas.79.5.1474

Kurachi, K., Davie, E. W., Strydom, D. J., Riordan, J. F., and Vallee, B. L. (1985). Sequence of the cDNA and gene for angiogenin, a human angiogenesis factor. Biochemistry 24, 5494-5499. doi: 10.1021/bi00341a032

Laneve, P., Gioia, U., Ragno, R., Altieri, F., Di Franco, C., Santini, T., et al. (2008). The tumor marker human placental protein 11 is an endoribonuclease. J. Biol. Chem. 283, 34712-34719. doi: 10.1074/jbc.M805759200

Leonidas, D. D., Shapiro, R., Allen, S. C., Subbarao, G. V., Veluraja, K., and Acharya, K. R. (1999). Refined crystal structures of native human angiogenin and two active site variants: implications for the unique functional properties of an enzyme involved in neovascularisation during tumour growth. J. Mol. Biol. 285, 1209-1233. doi: 10.1006/jmbi.1998.2378

Leonidas, D. D., Shapiro, R., Subbarao, G. V., Russo, A., and Acharya, K. R. (2002). Crystallographic studies on the role of the C-terminal segment of human angiogenin in defining enzymatic potency. Biochemistry 41, 2552-2562. doi: $10.1021 /$ bi015768q

Li, S., Lunse, C. E., Harris, K. A., and Breaker, R. R. (2015). Biochemical analysis of hatchet self-cleaving ribozymes. RNA 21, 1845-1851. doi: 10.1261/rna.052522. 115

Licht, K., Medenbach, J., Luhrmann, R., Kambach, C., and Bindereif, A. (2008). $3^{\prime}$-cyclic phosphorylation of U6 snRNA leads to recruitment of recycling factor p110 through LSm proteins. RNA 14, 1532-1538. doi: 10.1261/rna.112 9608

Lilley, D. M. (2011). Mechanisms of RNA catalysis. Philos. Trans. R. Soc. Lond. B Biol. Sci. 366, 2910-2917. doi: 10.1098/rstb.2011.0132

Lu, J., Esberg, A., Huang, B., and Bystrom, A. S. (2008). Kluyveromyces lactis gamma-toxin, a ribonuclease that recognizes the anticodon stem loop of tRNA. Nucleic Acids Res. 36, 1072-1080. doi: 10.1093/nar/gkm1121

Lu, J., Huang, B., Esberg, A., Johansson, M. J., and Bystrom, A. S. (2005). The Kluyveromyces lactis gamma-toxin targets tRNA anticodons. RNA 11, 16481654. doi: 10.1261/rna.2172105

Lu, Y., Liang, F. X., and Wang, X. (2014). A synthetic biology approach identifies the mammalian UPR RNA ligase RtcB. Mol. Cell 55, 758-770. doi: 10.1016/j. molcel.2014.06.032

Lund, E., and Dahlberg, J. E. (1992). Cyclic 2',3'-phosphates and nontemplated nucleotides at the $3^{\prime}$ end of spliceosomal U6 small nuclear RNA's. Science 255, 327-330. doi: 10.1126/science.1549778

Lyons, S. M., Achorn, C., Kedersha, N. L., Anderson, P. J., and Ivanov, P. (2016). YB-1 regulates tiRNA-induced Stress Granule formation but not translational repression. Nucleic Acids Res. 44, 6949-6960. doi: 10.1093/nar/gk w418

Maraia, R. J., and Bayfield, M. A. (2006). The La protein-RNA complex surfaces. Mol. Cell 21, 149-152. doi: 10.1016/j.molcel.2006.01.004

Maraia, R. J., and Intine, R. V. (2002). La protein and its associated small nuclear and nucleolar precursor RNAs. Gene Expr. 10, 41-57.

Mazumder, R., Iyer, L. M., Vasudevan, S., and Aravind, L. (2002). Detection of novel members, structure-function analysis and evolutionary classification of the $2 \mathrm{H}$ phosphoesterase superfamily. Nucleic Acids Res. 30, 5229-5243. doi: $10.1093 /$ nar/gkf645

McCracken, D. A., Martin, V. J., Stark, M. J., and Bolen, P. L. (1994). The linearplasmid-encoded toxin produced by the yeast Pichia acaciae: characterization and comparison with the toxin of Kluyveromyces lactis. Microbiology 140(Pt 2), 425-431. doi: 10.1099/13500872-140-2-425

Mets, T., Lippus, M., Schryer, D., Liiv, A., Kasari, V., Paier, A., et al. (2017). Toxins MazF and MqsR cleave Escherichia coli rRNA precursors at multiple sites. RNA Biol. 14, 124-135. doi: 10.1080/15476286.2016.1259784

Moll, I., and Engelberg-Kulka, H. (2012). Selective translation during stress in Escherichia coli. Trends Biochem. Sci. 37, 493-498. doi: 10.1016/j.tibs.2012.07. 007
Morad, I., Chapman-Shimshoni, D., Amitsur, M., and Kaufmann, G. (1993). Functional expression and properties of the tRNA(Lys)-specific core anticodon nuclease encoded by Escherichia coli prrC. J. Biol. Chem. 268, 26842-26849.

Mroczek, S., and Dziembowski, A. (2013). U6 RNA biogenesis and disease association. Wiley Interdiscip. Rev. RNA 4, 581-592. doi: 10.1002/wrna.1181

Mroczek, S., Krwawicz, J., Kutner, J., Lazniewski, M., Kucinski, I., Ginalski, K., et al. (2012). C16orf57, a gene mutated in poikiloderma with neutropenia, encodes a putative phosphodiesterase responsible for the U6 snRNA $3^{\prime}$ end modification. Genes Dev. 26, 1911-1925. doi: 10.1101/gad.193169.112

Myllykoski, M., Raasakka, A., Lehtimaki, M., Han, H., Kursula, I., and Kursula, P. (2013). Crystallographic analysis of the reaction cycle of $2^{\prime}, 3^{\prime}$-cyclic nucleotide $3^{\prime}$-phosphodiesterase, a unique member of the $2 \mathrm{H}$ phosphoesterase family. J. Mol. Biol. 425, 4307-4322. doi: 10.1016/j.jmb.2013.06.012

Namavar, Y., Barth, P. G., Kasher, P. R., van Ruissen, F., Brockmann, K., Bernert, G., et al. (2011). Clinical, neuroradiological and genetic findings in pontocerebellar hypoplasia. Brain 134(Pt 1), 143-156. doi: 10.1093/brain/awq287

Nasr, F., and Filipowicz, W. (2000). Characterization of the Saccharomyces cerevisiae cyclic nucleotide phosphodiesterase involved in the metabolism of ADP-ribose 1",2"-cyclic phosphate. Nucleic Acids Res. 28, 1676-1683. doi: $10.1093 /$ nar/28.8.1676

Nichols, N. M., and Yue, D. (2008). Ribonucleases. Curr. Protoc. Mol. Biol. 84, 3.13.1-3.13.8. doi: 10.1002/0471142727.mb0313s84

Nikolaev, Y., Deillon, C., Hoffmann, S. R., Bigler, L., Friess, S., Zenobi, R., et al. (2010). The leucine zipper domains of the transcription factors GCN4 and c-Jun have ribonuclease activity. PLoS One 5:e10765. doi: 10.1371/journal.pone. 0010765

Ogawa, T., Inoue, S., Yajima, S., Hidaka, M., and Masaki, H. (2006). Sequencespecific recognition of colicin E5, a tRNA-targeting ribonuclease. Nucleic Acids Res. 34, 6065-6073. doi: 10.1093/nar/gkl629

Ogawa, T., Tomita, K., Ueda, T., Watanabe, K., Uozumi, T., and Masaki, H. (1999). A cytotoxic ribonuclease targeting specific transfer RNA anticodons. Science 283, 2097-2100. doi: 10.1126/science.283.5410.2097

Ohara, T., Sakaguchi, Y., Suzuki, T., Ueda, H., and Miyauchi, K. (2007). The $3^{\prime}$ termini of mouse Piwi-interacting RNAs are 2'-O-methylated. Nat. Struct. Mol. Biol. 14, 349-350. doi: 10.1038/nsmb1220

Paushkin, S. V., Patel, M., Furia, B. S., Peltz, S. W., and Trotta, C. R. (2004). Identification of a human endonuclease complex reveals a link between tRNA splicing and pre-mRNA $3^{\prime}$ end formation. Cell 117, 311-321. doi: 10.1016/ S0092-8674(04)00342-3

Peebles, C. L., Gegenheimer, P., and Abelson, J. (1983). Precise excision of intervening sequences from precursor tRNAs by a membrane-associated yeast endonuclease. Cell 32, 525-536. doi: 10.1016/0092-8674(83)90472-5

Phizicky, E. M., and Hopper, A. K. (2010). tRNA biology charges to the front. Genes Dev. 24, 1832-1860. doi: 10.1101/gad.1956510

Pillon, M. C., Sobhany, M., Borgnia, M. J., Williams, J. G., and Stanley, R. E. (2017). Grc3 programs the essential endoribonuclease Las1 for specific RNA cleavage. Proc. Natl. Acad. Sci. U.S.A. 114, E5530-E5538. doi: 10.1073/pnas.170313 3114

Popow, J., Englert, M., Weitzer, S., Schleiffer, A., Mierzwa, B., Mechtler, K., et al. (2011). HSPC117 is the essential subunit of a human tRNA splicing ligase complex. Science 331, 760-764. doi: 10.1126/science.1197847

Popow, J., Schleiffer, A., and Martinez, J. (2012). Diversity and roles of (t)RNA ligases. Cell. Mol. Life Sci. 69, 2657-2670. doi: 10.1007/s00018-012-0944-2

Puerta-Fernandez, E., Romero-Lopez, C., Barroso-delJesus, A., and BerzalHerranz, A. (2003). Ribozymes: recent advances in the development of RNA tools. FEMS Microbiol. Rev. 27, 75-97. doi: 10.1016/S0168-6445(03)00020-2

Roberts, G. C., Dennis, E. A., Meadows, D. H., Cohen, J. S., and Jardetzky, O. (1969). The mechanism of action of ribonuclease. Proc. Natl. Acad. Sci. U.S.A. 62, 1151-1158. doi: 10.1073/pnas.62.4.1151

Roth, A., Weinberg, Z., Chen, A. G., Kim, P. B., Ames, T. D., and Breaker, R. R. (2014). A widespread self-cleaving ribozyme class is revealed by bioinformatics. Nat. Chem. Biol. 10, 56-60. doi: 10.1038/nchembio.1386

Russo, N., Shapiro, R., Acharya, K. R., Riordan, J. F., and Vallee, B. L. (1994). Role of glutamine-117 in the ribonucleolytic activity of human angiogenin. Proc. Natl. Acad. Sci. U.S.A. 91, 2920-2924. doi: 10.1073/pnas.91.8.2920

Salehi-Ashtiani, K., Luptak, A., Litovchick, A., and Szostak, J. W. (2006). A genomewide search for ribozymes reveals an HDV-like sequence in the human CPEB3 gene. Science 313, 1788-1792. doi: 10.1126/science.1129308 
Saville, B. J., and Collins, R. A. (1990). A site-specific self-cleavage reaction performed by a novel RNA in Neurospora mitochondria. Cell 61, 685-696. doi: 10.1016/0092-8674(90)90480-3

Saxena, S. K., Rybak, S. M., Davey, R. T. Jr., Youle, R. J., and Ackerman, E. J. (1992). Angiogenin is a cytotoxic, tRNA-specific ribonuclease in the RNase A superfamily. J. Biol. Chem. 267, 21982-21986.

Schifano, J. M., Cruz, J. W., Vvedenskaya, I. O., Edifor, R., Ouyang, M., Husson, R. N., et al. (2016). tRNA is a new target for cleavage by a MazF toxin. Nucleic Acids Res. 44, 1256-1270. doi: 10.1093/nar/gkv1370

Schifano, J. M., Edifor, R., Sharp, J. D., Ouyang, M., Konkimalla, A., Husson, R. N., et al. (2013). Mycobacterial toxin MazF-mt6 inhibits translation through cleavage of $23 \mathrm{~S}$ rRNA at the ribosomal A site. Proc. Natl. Acad. Sci. U.S.A. 110, 8501-8506. doi: 10.1073/pnas.1222031110

Schifano, J. M., Vvedenskaya, I. O., Knoblauch, J. G., Ouyang, M., Nickels, B. E., and Woychik, N. A. (2014). An RNA-seq method for defining endoribonuclease cleavage specificity identifies dual rRNA substrates for toxin MazF-mt3. Nat. Commun. 5:3538. doi: 10.1038/ncomms4538

Schillewaert, S., Wacheul, L., Lhomme, F., and Lafontaine, D. L. (2012). The evolutionarily conserved protein Las1 is required for pre-rRNA processing at both ends of ITS2. Mol. Cell. Biol. 32, 430-444. doi: 10.1128/MCB.06019-11

Schutz, K., Hesselberth, J. R., and Fields, S. (2010). Capture and sequence analysis of RNAs with terminal $2^{\prime}, 3^{\prime}$-cyclic phosphates. RNA 16, 621-631. doi: 10.1261/ rna.1934910

Scott, W. G., and Klug, A. (1996). Ribozymes: structure and mechanism in RNA catalysis. Trends Biochem. Sci. 21, 220-224. doi: 10.1016/S0968-0004(96)800193

Sekiguchi, J., and Shuman, S. (1997). Site-specific ribonuclease activity of eukaryotic DNA topoisomerase I. Mol. Cell 1, 89-97. doi: 10.1016/S10972765(00)80010-6

Serganov, A., and Patel, D. J. (2007). Ribozymes, riboswitches and beyond: regulation of gene expression without proteins. Nat. Rev. Genet. 8, 776-790. doi: $10.1038 / \mathrm{nrg} 2172$

Shapiro, R., Riordan, J. F., and Vallee, B. L. (1986). Characteristic ribonucleolytic activity of human angiogenin. Biochemistry 25, 3527-3532. doi: 10.1021/ bi00360a008

Shchepachev, V., Wischnewski, H., Missiaglia, E., Soneson, C., and Azzalin, C. M. (2012). Mpn1, mutated in poikiloderma with neutropenia protein 1 , is a conserved $3^{\prime}$-to- $5^{\prime}$ RNA exonuclease processing U6 small nuclear RNA. Cell Rep. 2, 855-865. doi: 10.1016/j.celrep.2012.08.031

Sheng, J., and $\mathrm{Xu}, \mathrm{Z}$. (2016). Three decades of research on angiogenin: a review and perspective. Acta Biochim. Biophys. Sin. 48, 399-410. doi: 10.1093/abbs/gmv131

Shigematsu, M., Honda, S., and Kirino, Y. (2018). Dumbbell-PCR for discriminative quantification of a small RNA variant. Methods Mol. Biol. 1680, 65-73. doi: 10.1007/978-1-4939-7339-2_4

Shigematsu, M., and Kirino, Y. (2015). tRNA-derived short non-coding RNA as interacting partners of argonaute proteins. Gene Regul. Syst. Biol. 9, 27-33. doi: $10.4137 /$ GRSB.S29411

Shih, I. H., and Been, M. D. (2002). Catalytic strategies of the hepatitis delta virus ribozymes. Annu. Rev. Biochem. 71, 887-917. doi: 10.1146/annurev.biochem. 71.110601 .135349

Shinya, S., Kadokura, H., Imagawa, Y., Inoue, M., Yanagitani, K., and Kohno, K. (2011). Reconstitution and characterization of the unconventional splicing of XBP1u mRNA in vitro. Nucleic Acids Res. 39, 5245-5254. doi: 10.1093/nar/ gkr132

Shuman, S. (1998). Polynucleotide ligase activity of eukaryotic topoisomerase I. Mol. Cell 1, 741-748. doi: 10.1016/S1097-2765(00)80073-8

Sidrauski, C., and Walter, P. (1997). The transmembrane kinase Irelp is a site-specific endonuclease that initiates mRNA splicing in the unfolded protein response. Cell 90, 1031-1039. doi: 10.1016/S0092-8674(00)8 0369-4

Sporn, M. B., Lazarus, H. M., Smith, J. M., and Henderson, W. R. (1969). Studies on nuclear exoribonucleases. 3. Isolation and properties of the enzyme from normal and malignant tissues of the mouse. Biochemistry 8, 1698-1706. doi: 10.1021/bi00832a053

Stark, M. J., and Boyd, A. (1986). The killer toxin of Kluyveromyces lactis: characterization of the toxin subunits and identification of the genes which encode them. EMBO J. 5, 1995-2002. doi: 10.1002/j.1460-2075.1986.tb04 455.x
Strydom, D. J., Fett, J. W., Lobb, R. R., Alderman, E. M., Bethune, J. L., Riordan, J. F., et al. (1985). Amino acid sequence of human tumor derived angiogenin. Biochemistry 24, 5486-5494. doi: 10.1021/bi00341a031

Tanaka, N., Chakravarty, A. K., Maughan, B., and Shuman, S. (2011a). Novel mechanism of RNA repair by RtcB via sequential $2^{\prime}, 3^{\prime}$-cyclic phosphodiesterase and $3^{\prime}$-Phosphate/5'-hydroxyl ligation reactions. J. Biol. Chem. 286, 4313443143. doi: 10.1074/jbc.M111.302133

Tanaka, N., Meineke, B., and Shuman, S. (2011b). RtcB, a novel RNA ligase, can catalyze tRNA splicing and HAC1 mRNA splicing in vivo. J. Biol. Chem. 286, 30253-30257. doi: 10.1074/jbc.C111.274597

Tanaka, N., and Shuman, S. (2011). RtcB is the RNA ligase component of an Escherichia coli RNA repair operon. J. Biol. Chem. 286, 7727-7731. doi: 10.1074/ jbc.C111.219022

Tello-Montoliu, A., Patel, J. V., and Lip, G. Y. (2006). Angiogenin: a review of the pathophysiology and potential clinical applications. J. Thromb. Haemost. 4, 1864-1874. doi: 10.1111/j.1538-7836.2006.01995.x

Telonis, A. G., Loher, P., Honda, S., Jing, Y., Palazzo, J., Kirino, Y., et al. (2015). Dissecting tRNA-derived fragment complexities using personalized transcriptomes reveals novel fragment classes and unexpected dependencies. Oncotarget 6, 24797-24822. doi: 10.18632/oncotarget.4695

Temmel, H., Muller, C., Sauert, M., Vesper, O., Reiss, A., Popow, J., et al. (2017). The RNA ligase RtcB reverses MazF-induced ribosome heterogeneity in Escherichia coli. Nucleic Acids Res. 45, 4708-4721.

Thiyagarajan, N., Ferguson, R., Subramanian, V., and Acharya, K. R. (2012). Structural and molecular insights into the mechanism of action of human angiogenin-ALS variants in neurons. Nat. Commun. 3:1121. doi: 10.1038/ ncomms 2126

Thompson, J. E., and Raines, R. T. (1994). Value of general Acid-base catalysis to ribonuclease a. J. Am. Chem. Soc. 116, 5467-5468. doi: 10.1021/ja00091a060

Tomita, K., Ogawa, T., Uozumi, T., Watanabe, K., and Masaki, H. (2000). A cytotoxic ribonuclease which specifically cleaves four isoaccepting arginine tRNAs at their anticodon loops. Proc. Natl. Acad. Sci. U.S.A. 97, 8278-8283. doi: $10.1073 /$ pnas. 140213797

Torchia, C., Takagi, Y., and Ho, C. K. (2008). Archaeal RNA ligase is a homodimeric protein that catalyzes intramolecular ligation of single-stranded RNA and DNA. Nucleic Acids Res. 36, 6218-6227. doi: 10.1093/nar/gkn602

Trotta, C. R., Miao, F., Arn, E. A., Stevens, S. W., Ho, C. K., Rauhut, R., et al. (1997). The yeast tRNA splicing endonuclease: a tetrameric enzyme with two active site subunits homologous to the archaeal tRNA endonucleases. Cell 89, 849-858. doi: 10.1016/S0092-8674(00)80270-6

Unterholzner, S. J., Poppenberger, B., and Rozhon, W. (2013). Toxin-antitoxin systems: biology, identification, and application. Mob. Genet. Elements 3:e26219. doi: $10.4161 /$ mge. 26219

Urano, F., Bertolotti, A., and Ron, D. (2000). IRE1 and efferent signaling from the endoplasmic reticulum. J. Cell Sci. 113(Pt 21), 3697-3702.

Vesper, O., Amitai, S., Belitsky, M., Byrgazov, K., Kaberdina, A. C., EngelbergKulka, H., et al. (2011). Selective translation of leaderless mRNAs by specialized ribosomes generated by MazF in Escherichia coli. Cell 147, 147-157. doi: 10. 1016/j.cell.2011.07.047

Ward, W. L., Plakos, K., and DeRose, V. J. (2014). Nucleic acid catalysis: metals, nucleobases, and other cofactors. Chem. Rev. 114, 4318-4342. doi: 10.1021/ cr400476k

Weinberg, Z., Kim, P. B., Chen, T. H., Li, S., Harris, K. A., Lunse, C. E., et al. (2015). New classes of self-cleaving ribozymes revealed by comparative genomics analysis. Nat. Chem. Biol. 11, 606-610. doi: 10.1038/nchembio.1846

Winkler, W. C., Nahvi, A., Roth, A., Collins, J. A., and Breaker, R. R. (2004). Control of gene expression by a natural metabolite-responsive ribozyme. Nature 428 , 281-286. doi: $10.1038 /$ nature 02362

Yajima, S., Inoue, S., Ogawa, T., Nonaka, T., Ohsawa, K., and Masaki, H. (2006). Structural basis for sequence-dependent recognition of colicin E5 tRNase by mimicking the mRNA-tRNA interaction. Nucleic Acids Res. 34, 6074-6082. doi: $10.1093 / \mathrm{nar} / \mathrm{gkl} 729$

Yamasaki, S., Ivanov, P., Hu, G. F., and Anderson, P. (2009). Angiogenin cleaves tRNA and promotes stress-induced translational repression. J. Cell Biol. 185, 35-42. doi: $10.1083 /$ jcb.200811106

Yang, Z., Ebright, Y. W., Yu, B., and Chen, X. (2006). HEN1 recognizes 21-24 nt small RNA duplexes and deposits a methyl group onto the $2^{\prime} \mathrm{OH}$ of the $3^{\prime}$ terminal nucleotide. Nucleic Acids Res. 34, 667-675. doi: 10.1093/nar/gkj474 
Yarmolinsky, M. B. (1995). Programmed cell death in bacterial populations. Science 267, 836-837. doi: 10.1126/science.7846528

Yoshihisa, T. (2014). Handling tRNA introns, archaeal way and eukaryotic way. Front. Genet. 5:213. doi: 10.3389/fgene.2014.00213

Yoshinari, S., Liu, Y., Gollnick, P., and Ho, C. K. (2017). Cleavage of 3'terminal adenosine by archaeal ATP-dependent RNA ligase. Sci. Rep. 7:11662. doi: 10.1038/s41598-017-11693-0

Zaug, A. J., Linger, J., and Cech, T. R. (1996). Method for determining RNA 3' ends and application to human telomerase RNA. Nucleic Acids Res. 24, 532-533. doi: 10.1093/nar/24.3.532

Zhang, K., and Kaufman, R. J. (2004). Signaling the unfolded protein response from the endoplasmic reticulum. J. Biol. Chem. 279, 25935-25938. doi: 10.1074/jbc. R400008200

Zhang, Y., Zhang, J., Hara, H., Kato, I., and Inouye, M. (2005a). Insights into the mRNA cleavage mechanism by MazF, an mRNA interferase. J. Biol. Chem. 280, 3143-3150. doi: 10.1074/jbc.M411811200

Zhang, Y., Zhu, L., Zhang, J., and Inouye, M. (2005b). Characterization of ChpBK, an mRNA interferase from Escherichia coli. J. Biol. Chem. 280, 26080-26088. doi: 10.1074/jbc.M502050200

Zhang, Y., Zhang, J., Hoeflich, K. P., Ikura, M., Qing, G., and Inouye, M. (2003). MazF cleaves cellular mRNAs specifically at ACA to block protein synthesis in Escherichia coli. Mol. Cell 12, 913-923. doi: 10.1016/S1097-2765(03)00402-7
Zhao, C., Tolkach, Y., Schmidt, D., Muders, M., Kristiansen, G., Muller, S. C., et al. (2018). tRNA-halves are prognostic biomarkers for patients with prostate cancer. Urol. Oncol. 36, 503.e1-503.e7. doi: 10.1016/j.urolonc.2018. 08.003

Zhelkovsky, A. M., and McReynolds, L. A. (2014). Polynucleotide $3^{\prime}$-terminal phosphate modifications by RNA and DNA ligases. J. Biol. Chem. 289, 3360833616. doi: 10.1074/jbc.M114.612929

Zinder, J. C., Wasmuth, E. V., and Lima, C. D. (2016). Nuclear RNA exosome at 3.1 A reveals substrate specificities, RNA paths, and allosteric inhibition of Rrp44/Dis3. Mol. Cell 64, 734-745. doi: 10.1016/j.molcel.2016.09.038

Conflict of Interest Statement: The authors declare that the research was conducted in the absence of any commercial or financial relationships that could be construed as a potential conflict of interest.

Copyright $(2018$ Shigematsu, Kawamura and Kirino. This is an open-access article distributed under the terms of the Creative Commons Attribution License (CC BY). The use, distribution or reproduction in other forums is permitted, provided the original author(s) and the copyright owner(s) are credited and that the original publication in this journal is cited, in accordance with accepted academic practice. No use, distribution or reproduction is permitted which does not comply with these terms. 